\title{
Comparison of Cement-Based and Polymer-Based Concrete Pipes for Analysis of Cost Assessment
}

\author{
Orhan Bozkurt ${ }^{1}$ and Mehmet İslamoğlu ${ }^{2}$ \\ ${ }^{1}$ Inegol Faculty of Business, Uludag University, 16400 Bursa, Turkey \\ ${ }^{2}$ Economics Department, Bartın University, 74100 Bartın, Turkey \\ Correspondence should be addressed to Orhan Bozkurt; obozkurt@uludag.edu.tr
}

Received 28 March 2013; Accepted 8 May 2013

Academic Editor: Osman Gencel

Copyright (c) 2013 O. Bozkurt and M. İslamoğlu. This is an open access article distributed under the Creative Commons Attribution License, which permits unrestricted use, distribution, and reproduction in any medium, provided the original work is properly cited.

\begin{abstract}
As the variety of materials utilized in construction industry has expanded, new techniques have been used in order to optimize the quality and efficiency of output. Therefore, recent innovations taking place in the construction industry led researchers to increase the mechanical efficiency of the output more than the cost effectiveness of it. However, especially professionals experiencing in the industry look into the cost effectiveness of the work. In other words, they also want researchers to justify the innovative techniques economically. The aim of this study is to provide a comparative analysis of the cost efficiency of polymer concrete used to manufacture durable and long-lasting reinforced concrete structures.
\end{abstract}

\section{Introduction}

Concretes are the most widely used construction materials in the world; a large variety of concretes are based on a variety of cements [1]. Low costs, ease of application, and high compressive strength are the main factors to be considered for a given application. Inorganic (mineral) concrete based on the Portland cement has shortcomings: poor flexural strength, low tensile strength, high porosity, freeze thaw deterioration, destruction by corrosive chemicals, and so forth [2]. These shortcomings are viewed as more and more acute since we have become more and more concerned with conservation of energy and materials. One approach is based on a combination of technologies of concrete and that of polymers. Thus, polymer concrete (PC) materials have become a viable choice for the civil construction sector in developed countries, particularly in applications such as making reinforced slabs, overlays for highway pavements, bridge decks, retaining walls, water tanks, and pipe lines, PCs are also used in repairing deteriorated mineral concretes (Portland cement concrete) in situations when high strength, fast cure, and durability are required [3]. Polymer concretes are composites in which the aggregates are bound together in a polymer matrix. They do not contain Portland cement.
Underground pipe systems have presented to improve human beings' standard of living since the dawn of civilization. Concrete pipes are frequently used in sewerage and storm water systems, under and over ground irrigation facilities, water transmission lines, water tanks, water towers, pumping lines, pumping stations, and water structures, such as tunnels. These concrete pipes are exposed to various harmful effects during their service life. However, factors leading to deterioration in cement-based concrete pipes may originate from physical, chemical, mechanical, or biological effects. Impact, wear, and erosion are some damages that occur mechanically. Chemical effects might occur, due to harmful substances leaking into the concrete or materials used in concrete production, as well. Common chemical effects are alkali-silica reactions, sulfate attacks, carbonation, corrosion, acid, and salt. Physical causes of deterioration are freeze-thaw, solvent salts, high temperatures, and so on [4].

Studies have been carried out to make more durable concrete pipes and prevent the aforementioned harmful effects since concrete pipes have been widely utilized for managing storm water, sewage, and drainage for more than a century as mentioned before. Deterioration of concrete pipes constitutes a serious problem to society. It has been reported that annual maintenance and repair costs of deteriorated concrete pipes 
in Canada in the early 1990s were approximately $\$ 2.5$ billion dollars [6].

There are many types of piping materials in the construction sector today, ranging from rigid concrete to flexible thermal plastic. Pipes must have adequate strength and/or stiffness to perform their intended function. They must also be durable enough to last for their lifetime. With the usage of polymers in concrete technology, the concrete nature has increased significantly. Many important changes have occurred regarding the utilization of polymer in concrete technology, and presently the researches about polymer composites still continue. Typically polymer concrete has a longer maintenance-free service life than Portland cement concrete and possesses also other advantages compared to Portland cement concrete such as increased bond strength (bonding to previously existing concrete); increased freezethaw resistance; high abrasion resistance; increased flexural, compressive and tensile strengths; fast setting times (curing within 1 or $2 \mathrm{~h}$ ); good durability; improved chemical resistance in harsh environments. Moreover, they exhibit good creep resistance and are highly UV resistant due to the very low polymer content and inert fillers. On the other hand, they exhibit reduced elastic modulus. The loss of strength can be attributed to an increase of porosity in polymer concrete with increased capillary diffusion of solutions, which weakens the bond between the aggregate and the matrix [3]. As clearly understood here, to decrease repair cost and to increase service life of pipes, polymer composites present a perfect choice.

A study was conducted in order to predict the remaining lifetime of preset pipes. In the study, four different used polyethylene pipes for gas and water supply with an age of up to more than 30 years have been investigated with respect to molecular and morphological changes. The molecular analysis did not show any significant polymer degradation as an indication of ageing of the materials [7].

In this study, cost analyses of cement-based concrete pipes and polymer concrete pipes were evaluated.

\section{Methods of Calculating Manufacturing Cost}

Nowadays, the calculation of the manufacturing cost gained an increasing importance. Cost saving will have a significant positive impact on decrease of firm costs and increase profitability [8]. The knowledge related to the unit cost determines the level of the price quote. Being able to offer a good price quote depends on the knowledge about the cost structure of the products. Therefore, the costs should be calculated accurately and the accounting should be done correctly. In management, the costs are generally composed of direct labor (55\%), raw materials $(35 \%)$, and manufacturing overheads (10\%) [9]. The manufacturing overheads in the construction businesses are usually at this level. Direct labour cost forms the largest part of the total costs. Labor costs affect the profitability of a company [10]. The use of good quality products in order to diminish these costs may be considered as a solution for decreasing the total cost. While the use of high-quality products does not increase the construction costs, it ensures the fall of the cost in general by reinforcing the construction resistance [11].
Due to maintenance and repair costs being in excess in the construction businesses, it becomes a requirement to use more resistant raw material and auxiliary material. To protect concrete structures from physical, chemical, or biological degradation and increase their durability, high performance protective surface coating materials can be used [12].

All the motives suggest the calculation and the accounting of the costs to be done in a more accurate way. Otherwise, these costs might cause financial capital loss by increasing over time [13]. While the cost accounting is used in the cost calculation of the produced goods and services; it creates some effects in the management decisions and makes contributions for offering price quotes. In Turkey, the uniform cost accounting implementers have been organized in 1989 by the Professional Law number 3568. The general communiqué on accounting system application of December 26, 1992, has come into effect legally in January the 1st, 1994. It is required through the communique to declare the accounts as 1-9 kinds of expenses and 10-99 kinds of revenues. Furthermore, in application of cost accounting, new approaches such as 7/A and 7/B options have been introduced [14].

The construction activities last usually longer than one year. The construction activities are varied and have different features. In the determination of loss and profit in the construction businesses, it is waited in order to have the job achieved or the loss or profit is calculated as estimation at the end of every period. In the construction sector, the full cost method based on orders is usually applied. In this method through which all of the production expenses within the period are ascribed to the production cost, the product cost is composed of all of the production expenses. Pursuant to this, the total of the direct raw materials and supplies expenses, direct labor expenses, variable production overheads and fixed production overheads, give the "full cost" [15].

In the construction activities, the start-up expenses are important elements of the cost. These expenses are present particularly during the foundation stage. The use of nondurable materials and the repair and maintenance expenses in a short time decrease the return on capital. Meanwhile, it extends the return time of the investments. Furthermore, the increase of labor and material expenses at every stage of repair and maintenance suggests the requirement for more resistant products to be used in the construction businesses. Exactly at this point, the use of polymer concrete technology in manufacturing process becomes a crucial part of the activity. This method while enabling the construction resistance on the one hand, decreases the repair, maintenance, and labor expenses on the other hand. In Figure 1, below the cost elements are shown in total.

According to the Tax Procedure Law number 315, taxpayers will declare their assets subject to amortization with respect to rates announced by Ministry of Finance of the Republic of Turkey. In determining the rates of economic assets to be declared, their estimated service lives are taken into account. In accordance with Tax Procedure Law number 315, Communiqués 333, 339, and 365 are published which are related to amortization periods or service life of tangible assets subject to amortization or depreciation [16]. Communiqué 333 on Tax Procedure Law number 315 under the title 


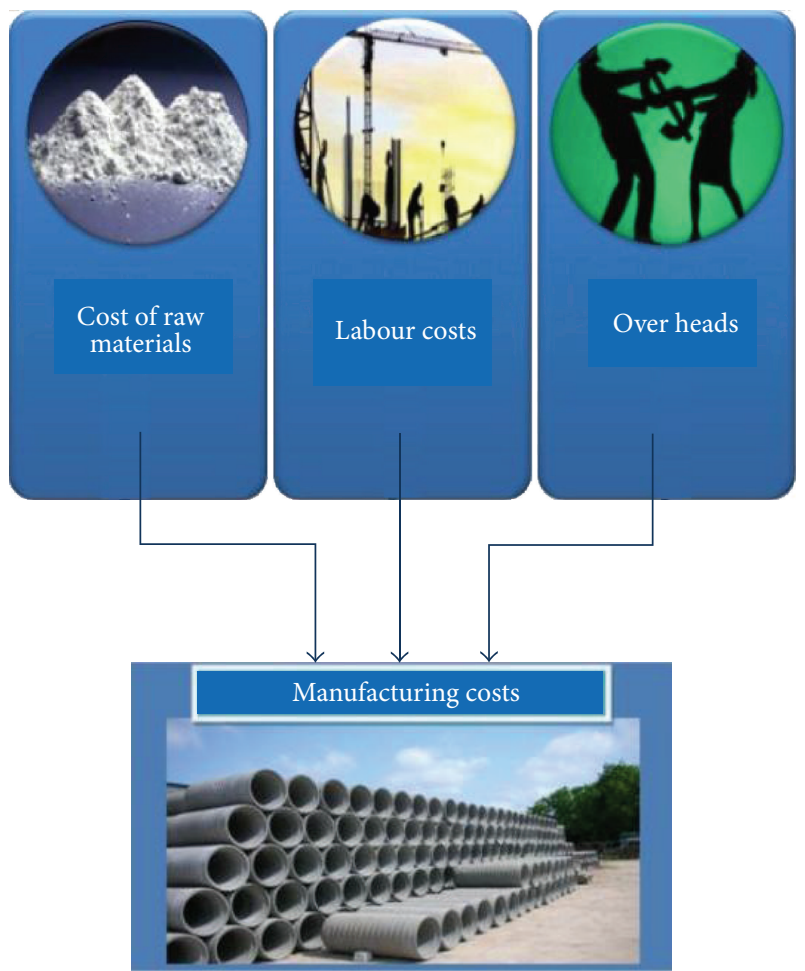

FIGURE 1: Cost of manufacturing process in construction industry.

of Plant and Land Regulations introduces service life of cement-based retrieval systems and pipes used for sewers and other supplementary materials as 15 years and orders amortization of said assets during this period. When cementbased concrete pipes have an average of 15 years of service life, it is well known that polymer-based concrete pipes are designed for a service life longer than 50 years.

\section{Formulations}

In polymer concrete manufacture, $\mathrm{PC}_{t}$ requires care in the casting process, attention to curing temperature, composition, and careful choice in type of resins and aggregates. The latter involve several linked characteristics: specific area, interfaces with the matrix, strength and deformability, shape, and size. For example, aggregates with irregular shapes and high surface area improve the anchorage with the matrix. The proportion of thermosetting resin to aggregate as well as different types of aggregate varies in different formulations of $\mathrm{PC}_{t}$. In principle, the mix design of $\mathrm{PC}_{t}$ typically involves an aggregate size gradation to provide the lowest possible void volume that will require the minimum polymeric binder concentration necessary to coat the aggregates and to fill the voids [3]. Several different formulations for polymer concretes are presented in Table 1.

In Portland cement concrete production, the used materials are Portland cement (generally CEM I 42.5), aggregates, water, and additives.

Portland cement concrete mixture proportion for pipe is presented in Table 2. Detailed production procedure has been reported in the literature $[4,6,17-19]$.
TABLE 1: Several different formulations [3].

\begin{tabular}{lccc}
\hline $\begin{array}{l}\text { Epoxy resin } \\
\text { (wt.\%) }\end{array}$ & $\begin{array}{c}\text { Polyester resin } \\
\text { (wt.\%) }\end{array}$ & Sand (wt.\%) & $\begin{array}{c}\text { Catalyst } \\
\text { (MEKP) (wt.\%) }\end{array}$ \\
\hline 20.0 & - & 78.5 & 1.5 \\
20.0 & - & 78.0 & 2.0 \\
- & 10.0 & 88.5 & 1.5 \\
- & 15.0 & 83.5 & 1.5 \\
- & 18.0 & 80.5 & 1.5 \\
- & 20.0 & 77.5 & 2.5 \\
- & 20.0 & 78.0 & 2.0 \\
\hline
\end{tabular}

\section{Results and Discussion}

4.1. Cost Assessment of Several Different Polymer-and CementBased Concrete Pipes. In Table 3, diameters, inner and outer wall thickness, and length and weight specifications are given for the different sizes of polymer-based and cement-based concrete pipes. In the table, when PP denotes polymer-based concrete pipes, CP represents the cement-based concrete pipes. In Table 3, polymer- and cement-based concrete pipes existing with a wide range are the types which are commercially sold the most. In the table, first, the prices of all sizes of the pipes are obtained, and then in order to make comparison, for each pipe code, on the basis of meters, unit prices are calculated, and thus normalized prices are found.

\subsection{Comparison of Polymer- and Cement-Based Concrete} Pipes in Terms of Cost Effectiveness. Assuming that PP5coded polymer-based concrete pipes and CP5-coded cementbased concrete pipes are used for infrastructure work, recognizing that other expenses remains the same and a change in manufacturing conditions is ignored, we implemented a cost comparison for each pipe depending on their market prices shown in Table 3. We prepared two separate tables for each pipe in order to compare their total costs in pursuit of completion of infrastructure work. Much as the initial set-up cost for 1000 units of PP5 and CP5 is $\$ 103000$ and $\$ 14000$, respectively, the condition is reversed in the long run. According to the obtained results, considering the useful life of polymer-based concrete pipes depending on its technology, costs are notably reduced. Polymer-based technology results in a service life 3.3 times longer than cement-based technology (service life of polymer-based concrete pipes is designed for a period of time no less than 50 years, whereas cement-based concrete pipes have a useful life of 15 year). Regarding the infrastructure work in which polymer-based concrete pipes are used, relying on its longer service life, the labor costs do not repeat as in cement-based concrete technology; therefore, it presents a significant cost advantage. In light of The previously mentioned facts, with the usage of polymer-based concrete pipe as a construction material, it is probable to avoid aforementioned construction costs. Here, longevity of polymer-based concrete pipes is our main motivation for implementing this study.

In Figure 2, it is obvious that labour cost comprises important part of the construction work. Completed units 
TABLE 2: Concrete industries mix design $\left(\right.$ per $\left.\mathrm{m}^{3}\right)$.

\begin{tabular}{lccccc}
\hline Sand $(\mathrm{kg})$ & Rock $(\mathrm{kg})$ & Fly Ash $(\mathrm{kg})$ & Cement $(\mathrm{kg})$ & Water $(\mathrm{kg})$ & WRA $(\mathrm{L})$ \\
\hline 1510 & 448 & 73.5 & 294 & 98.9 \\
\hline
\end{tabular}

WRA: Water reducing admixture.

TABLE 3: Cost assessment of several different polymer and cement-based concrete pipes.

\begin{tabular}{|c|c|c|c|c|c|}
\hline Codes & Inside diameter, $\mathrm{mm}$ & Outside diameter, $\mathrm{mm}$ & Wall thickness, $\mathrm{mm}$ & Weight, $\mathrm{kg} / \mathrm{m}$ & Normalized price \\
\hline PP1 & 415 & 427 & 12 & 17 & $46 \$ / \mathrm{m}$ \\
\hline PP2 & 515 & 530 & 15 & 26 & $57 \$ / m$ \\
\hline PP3 & 615 & 633 & 18 & 35 & $68 \$ / \mathrm{m}$ \\
\hline PP4 & 698 & 718 & 20 & 48 & $88 \$ / \mathrm{m}$ \\
\hline PP5 & 797 & 820 & 23 & 62 & $103 \$ / \mathrm{m}$ \\
\hline PP6 & 1592 & 1638 & 46 & 243 & $320 \$ / \mathrm{m}$ \\
\hline PP7 & 2386 & 2453 & 67 & 542 & $681 \$ / \mathrm{m}$ \\
\hline PP8 & 2981 & 3065 & 84 & 843 & $1039 \$ / \mathrm{m}$ \\
\hline PP9 & 3974 & 4085 & 111 & 1487 & $1853 \$ / \mathrm{m}$ \\
\hline $\mathrm{CP1}$ & 150 & 178 & 28 & 49 & $3 \$ / m$ \\
\hline $\mathrm{CP} 2$ & 200 & 236 & 36 & 90 & $4 \$ / \mathrm{m}$ \\
\hline $\mathrm{CP} 3$ & 300 & 345 & 45 & 133 & $7 \$ / \mathrm{m}$ \\
\hline $\mathrm{CP} 4$ & 400 & 450 & 50 & 200 & $10 \$ / \mathrm{m}$ \\
\hline CP5 & 500 & 565 & 65 & 294 & $14 \$ / \mathrm{m}$ \\
\hline CP6 & 600 & 670 & 70 & 389 & $18 \$ / \mathrm{m}$ \\
\hline
\end{tabular}



Figure 2: The cost of goods model (adapted from Jackson et al., 2009) [5].

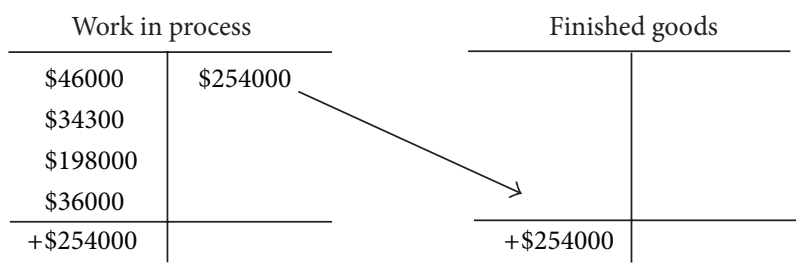

Figure 3: The cost of goods model (adapted from Jackson et al., 2009) [5].

related to manufacturing process are recorded in manufacturing accounts. It is seen in the figure that the total cost of manufacturing process adds up to $\$ 343000$. As it is shown in Table 5, the total costs incorporate $\$ 6000$, the remaining balance from the previous period, $\$ 103000$, cost of raw material, $\$ 198000$, direct labour cost, and $\$ 36000$, manufacturing overheads.
In Figure 3, except for raw materials, we assume that costs of the other elements remain the same as in Figure 2. In Table 6, the total cost of manufacturing process comes to $\$ 254000$, and the cost of raw materials used in the process is $\$ 14000$. However, the cost of raw materials used seems far lower when compared to polymeric pipes; the service life of polymeric pipes helps to compensate this reverse condition as shown in Table 4 . At the same time, longer service life provides a significant savings at direct labour costs and manufacturing overheads including maintenance and repair costs by preventing recurring outlays.

In Table 7 below, the polymer- and cement-based concrete pipes are compared not only regarding their material cost, but they are also assessed by considering the total cost of the whole manufacturing or installation process. For PP5 and CP5-coded pipes which basically fulfill the same functions, taking their service life into account, total annual cost of them is calculated. According to the results, in spite of the high cost of raw materials, if we consider the entire manufacturing process, the installation which is implemented by using polymer technology is around two and a half times lower in cost.

The following equations show us total cost covered for installation process and the proportions of cost elements within installation process:

$$
C_{t}=C_{r}+C_{d}+C_{m},
$$

where $C_{r}=$ cost of raw materials and beginning inventory; $C_{d}=$ direct labour cost; $C_{m}=$ manufacturing overheads; $C_{t}=$ total cost per installation process. 
TABLE 4: Comparison of polymer and cement-based concrete pipes.

\begin{tabular}{lccccc}
\hline Code & Price, $\$$ & Amount utilized, $m$ & Total cost, $\$$ & Total cost/year & Annual cost \\
\hline PP5 & 103 & 1000 & 103000 & $103000 / 50$ & $2060 \$ /$ year \\
CP5 & 14 & 1000 & 14000 & $14000 / 15$ & $933 \$ /$ year \\
\hline
\end{tabular}

TABLE 5: Cost of PP5 construction account.

\begin{tabular}{lcc}
\hline Description & Item & Amount \\
\hline $\begin{array}{l}\text { Work in the beginning of } \\
\text { the period }\end{array}$ & $\begin{array}{c}\text { Beginning inventory of } \\
\text { Raw materials used }\end{array}$ & $\$ 6000$ \\
$\begin{array}{l}\text { The amount of direct } \\
\text { labor cost incurred }\end{array}$ & + Raw material used & $\$ 103000$ \\
$\begin{array}{l}\text { Manufacturing overhead } \\
\text { incurred }\end{array}$ & $\begin{array}{c}\text { + Manufacturing } \\
\text { overhead }\end{array}$ & $\$ 198000$ \\
$\begin{array}{l}\text { The cost of goods } \\
\text { manufactured period }\end{array}$ & $\begin{array}{c}\text { Cost of goods } \\
\text { manufactured }\end{array}$ & $=\$ 343000$ \\
\hline
\end{tabular}

TABLE 6: Cost of CP5 construction account.

\begin{tabular}{lcc}
\hline Description & Item & Amount \\
\hline $\begin{array}{l}\text { Work in the beginning of } \\
\text { the period }\end{array}$ & $\begin{array}{c}\text { Beginning inventory of } \\
\text { Raw materials used }\end{array}$ & $\$ 6000$ \\
$\begin{array}{l}\text { The amount of direct } \\
\text { labor cost incurred }\end{array}$ & + Raw material used & $\$ 14000$ \\
$\begin{array}{l}\text { Manufacturing overhead } \\
\text { incurred }\end{array}$ & $\begin{array}{c}\text { + Manufacturing } \\
\text { overhead }\end{array}$ & $\$ 198000$ \\
$\begin{array}{l}\text { The cost of goods } \\
\text { manufactured period }\end{array}$ & $\begin{array}{c}\text { Cost of goods } \\
\text { manufactured }\end{array}$ & $=\$ 254000$ \\
\hline
\end{tabular}

Consider the following:

$$
W_{t}=\left(\frac{C_{r}}{C_{t}}\right)+\left(\frac{C_{d}}{C_{t}}\right)+\left(\frac{C_{m}}{C_{t}}\right)=W_{r}+W_{d}+W_{m}=1
$$

where $W_{r}=$ proportion of cost of raw materials and beginning inventory within total cost of installation process; $W_{d}=$ proportion of direct labour cost within total cost of installation process; $W_{m}=$ proportion of manufacturing overheads within total cost of installation process; $W_{t}=$ proportion of total cost.

By applying the latter formula, we can easily obtain the proportions of cost elements for each installation processes:

$$
\begin{aligned}
W_{t \mathrm{pp} 5} & =\left[\frac{103000+6000}{343000}\right]+\left[\frac{198000}{343000}\right]+\left[\frac{36000}{343000}\right] \\
& =32 \%+58 \%+10 \%=1 \\
W_{t \mathrm{cp} 5} & =\left[\frac{14000+6000}{254000}\right]+\left[\frac{198000}{254000}\right]+\left[\frac{36000}{254000}\right] \\
& =8 \%+78 \%+14 \%=1 .
\end{aligned}
$$

The allocation of annual costs is implemented in accordance with the proportions of cost types within total cost in Table 7. It is apparent that if we consider the long-term

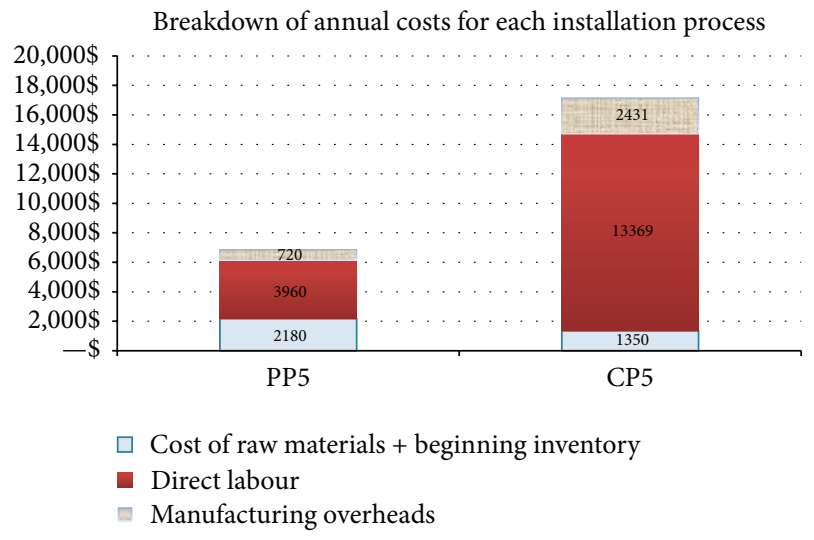

FIGURE 4: Breakdown of annual cost for each installation process using PP5 and CP5-coded pipes.

benefit of the investments, installation implemented by using polymer technology is far more economic than the other choice. In Table 8, the proportions calculated before are used to obtain cost elements per total annual costs for each installation process.

The breakdown of annual cost for each installation process using PP5 and CP5-coded pipes is also displayed in Figure 4.

\section{Conclusion}

Since acquisition cost in construction industry has become a crucial matter today, in terms of minimizing labour, maintenance and repair costs, polymer technology offers a challenging opportunity. In particular, at construction work related to infrastructure, polymer concrete pipe system helps to reduce maintenance, repair, and labour costs significantly by extending the useful life of the investment. Particularly, pipe produced by this technology provides a longer service life with its high technical specifications such as being strong and corrosion resistant.

Scientific researchers have proved for so long that polymer-based concrete pipes have a few times longer service lives compared to cement-based concrete pipes. High material cost of polymer-based concrete pipes should be disregarded as they present a new choice in place of cement-based concrete pipes by reconstruction and maintenance-free service life for a long period of time. In the analysis, according to cost estimation results related to installation processes using $\mathrm{CP}$ and PP, the total cost of PP per year is equal to nearly $40 \%$ cost of CP. So, in the long run, we can conclude that polymer pipe 
TABLE 7: Comparison of installation processes in terms of financial cost.

\begin{tabular}{lccccccccc}
\hline Code & Price $\$$ & $\begin{array}{c}\text { Amount } \\
\text { utilized, } m\end{array}$ & $\begin{array}{c}\text { Cost of raw } \\
\text { materials, } \$\end{array}$ & $\begin{array}{c}\text { Direct } \\
\text { labour, } \$\end{array}$ & $\begin{array}{c}\text { Manufacturing } \\
\text { overheads, } \$\end{array}$ & $\begin{array}{c}\text { Beginning } \\
\text { inventory, } \$\end{array}$ & Total cost, \$ & $\begin{array}{c}\text { Service life, } \\
\text { years }\end{array}$ & $\begin{array}{c}\text { Total cost per } \\
\text { year, \$ }\end{array}$ \\
\hline PP5 & 103 & 1000 & 103000 & 198000 & 36000 & 6000 & 343000 & 50 & 6860 \\
CP5 & 14 & 1000 & 14000 & 198000 & 36000 & 6000 & 254000 & 15 & 17150 \\
\hline
\end{tabular}

TABLE 8: Breakdown of annual costs for each installation process.

\begin{tabular}{lcccc}
\hline Type & PP5, $\$$ & $W_{t \mathrm{pp} 5}$ & $\mathrm{CP} 5, \$$ & $W_{t \mathrm{cp} 5}$ \\
\hline$C_{r}$ & 2180 & $32 \%$ & 1350 & $8 \%$ \\
$C_{d}$ & 3960 & $58 \%$ & 13369 & $78 \%$ \\
$C_{m}$ & 720 & $10 \%$ & 2431 & $14 \%$ \\
$C_{t}$ & 6860 & $100 \%$ & 17150 & $100 \%$ \\
\hline
\end{tabular}

technology is far more cost effective compared to cementbased technology. It is also apparent that the cost analysis is very useful, essential, and demanded by all industries while a new material research is being done.

\section{References}

[1] E. A. Bobadilla-Sánchez, G. Martínez-Barrera, W. Brostow, and T. Datashvili, "Effects of polyester fibers and gamma irradiation on mechanical properties of polymer concrete containing $\mathrm{CaCO}_{3}$ and silica sand," Express Polymer Letters, vol. 3, no. 10, pp. 615-620, 2009.

[2] O. Gencel, W. Brostow, G. Martínez-Barrera, and M. S. Gok, "Mechanical properties of polymer concretes containing different amount of hematite or colemanite," Polimery, vol. 57, no. 4, pp. 17-24, 2012.

[3] G. Martinez-Barrera, E. Vigueras-Santiago, O. Gencel, and H. E. Hagg Lobland, "Polymer concretes: a description and methods for modification and improvement," Journal of Materials Education, vol. 33, no. 1-2, pp. 37-52, 2011.

[4] H. Binici, M. Y. Durguna, T. Rızaoğlu, and M. Koluçolak, "Investigation of durability properties of concrete pipes incorporating blast furnace slag and ground basaltic pumice as fine aggregates," Scientia Iranica, vol. 19, no. 3, pp. 366-372, 2012.

[5] S. R. Jackson, R. B. Sawyers, and J. G. Jenkins, Managerial Accounting: A Focus on Ethical Decision Making, 5th edition, 2009.

[6] V. Rostami, Y. Shao, and A. J. Boyd, "Durability of concrete pipes subjected to combined steam and carbonation curing," Construction and Building Materials, vol. 25, no. 8, pp. 33453355, 2011.

[7] A. Frank, G. Pinter, and R. W. Lang, "Prediction of the remaining lifetime of polyethylene pipes after up to 30 years in use," Polymer Testing, vol. 28, no. 7, pp. 737-745, 2009.

[8] M. Hultman, M. J. Robson, and C. S. Katsikeas, "Export product strategy fit and performance: an empirical investigation," Journal of International Marketing, vol. 17, no. 4, pp. 1-23, 2009.

[9] U. Ergun and B. E. Karamaras, "Comparison of two contemporary approach to management accounting: activity-based costing and theory of constraints," Muhasebe Bilim Dünyasi Dergisi, vol. 4, no. 1, 2002.

[10] Z. J. Acs and D. B. Audretsch, "Innovation, market structure and firm size," The Review of Economics and Statistics, vol. 64, no. 4, pp. 567-574, 1987.
[11] R. Kanit, O. Ozkan, and M. Gunduz, "Cost assessment of concrete and steel types for office buildings: an exploratory study," Building and Environment, vol. 42, no. 9, pp. 3404-3409, 2007.

[12] S. Mortezania and F. Othman, "Cost analysis of pipes for application in sewage systems," Materials and Design, vol. 33, pp. 356-361, 2011.

[13] G. Cassar and J. Craig, "An investigation of hindsight bias in nascent venture activity," Journal of Business Venturing, vol. 24, no. 2, pp. 149-164, 2009.

[14] S. Yükçü, Cost Accounting in Terms of Management, Anadolu Matbaacilik, İzmir, Turkey, 1998.

[15] S. Sevgener and R. Hacirüstemoğlu, Management Accounting, Alfa Basim Yayin Dağıtım, İstanbul, Turkey, 2000.

[16] Ministry of Finance of the Republic of Turkey, Tax Procedure Law, no. 315.

[17] C. Berryman, J. Zhu, W. Jensen, and M. Tadros, "Highpercentage replacement of cement with fly ash for reinforced concrete pipe," Cement and Concrete Research, vol. 35, no. 6, pp. 1088-1091, 2005.

[18] T. Haktanir, K. Ari, F. Altun, C. D. Atis, and O. Karahan, "Effects of steel fibers and mineral filler on the water-tightness of concrete pipes," Cement and Concrete Composites, vol. 28, no. 9, pp. 811-816, 2006.

[19] L. Hui and L. Yongbiao, "Fabricating technology for concrete pipes," IERI Procedia, vol. 1, pp. 124-130, 2012. 

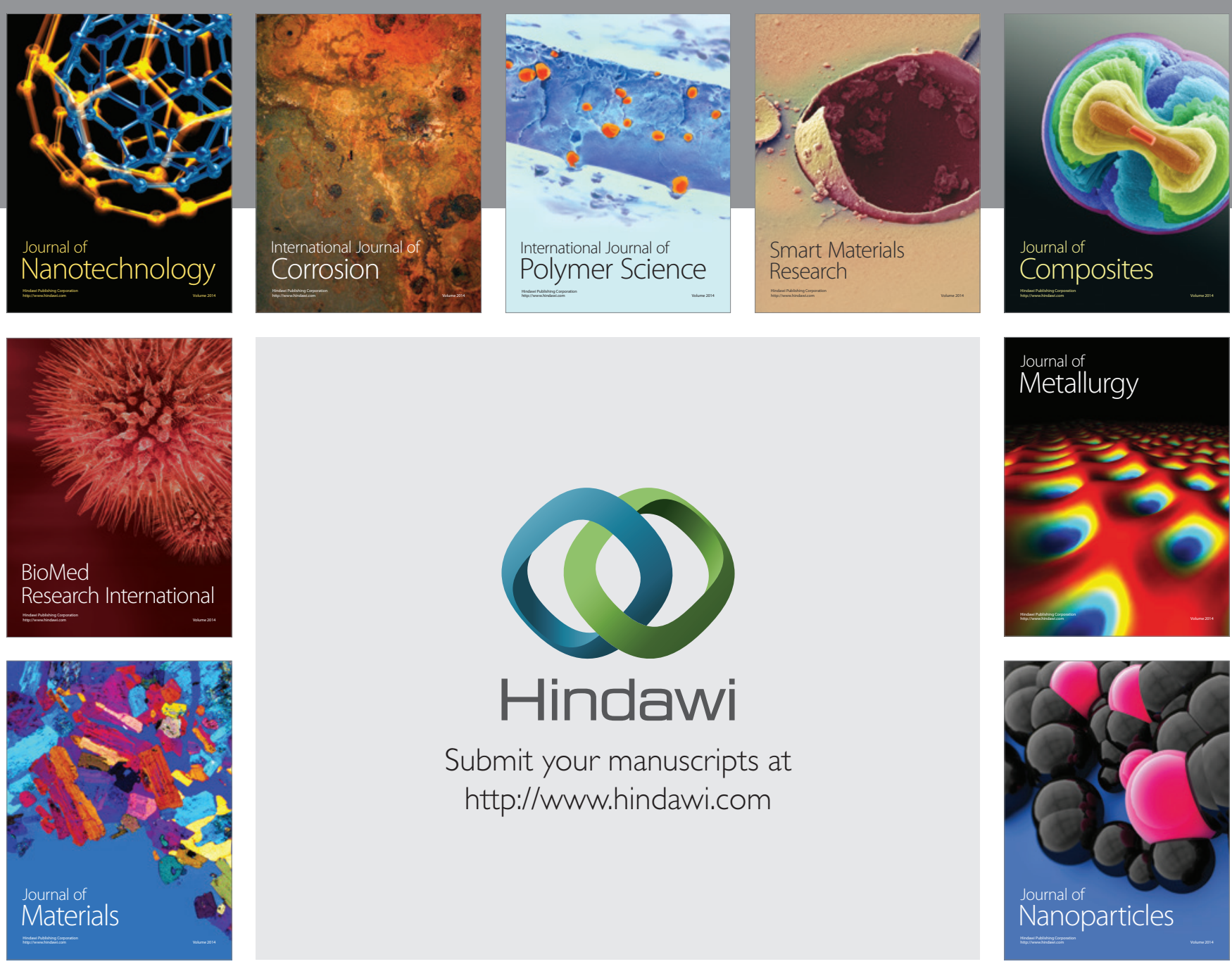

Submit your manuscripts at http://www.hindawi.com
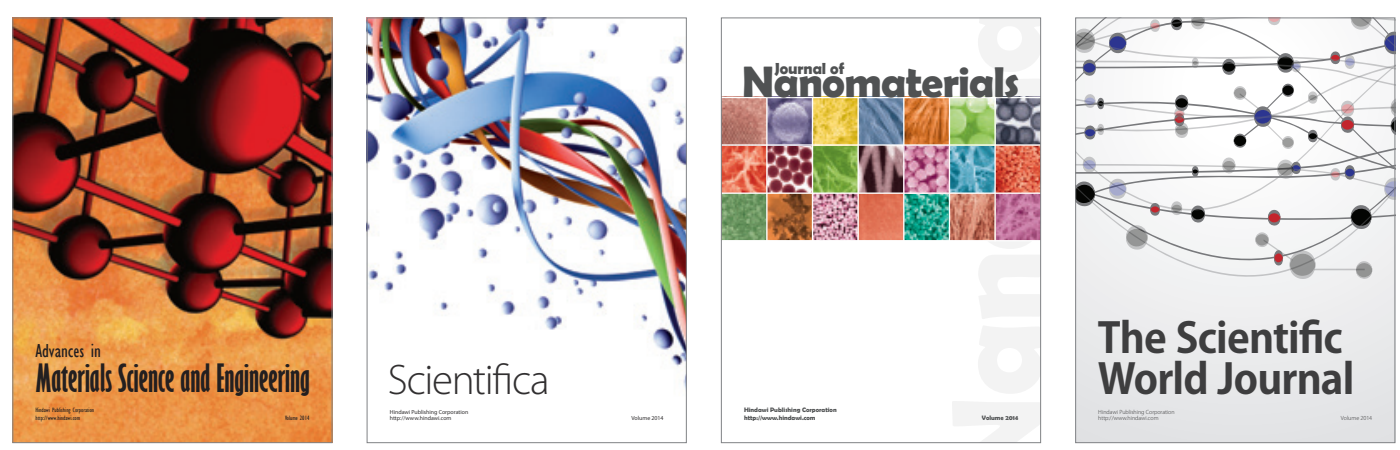

\section{The Scientific World Journal}
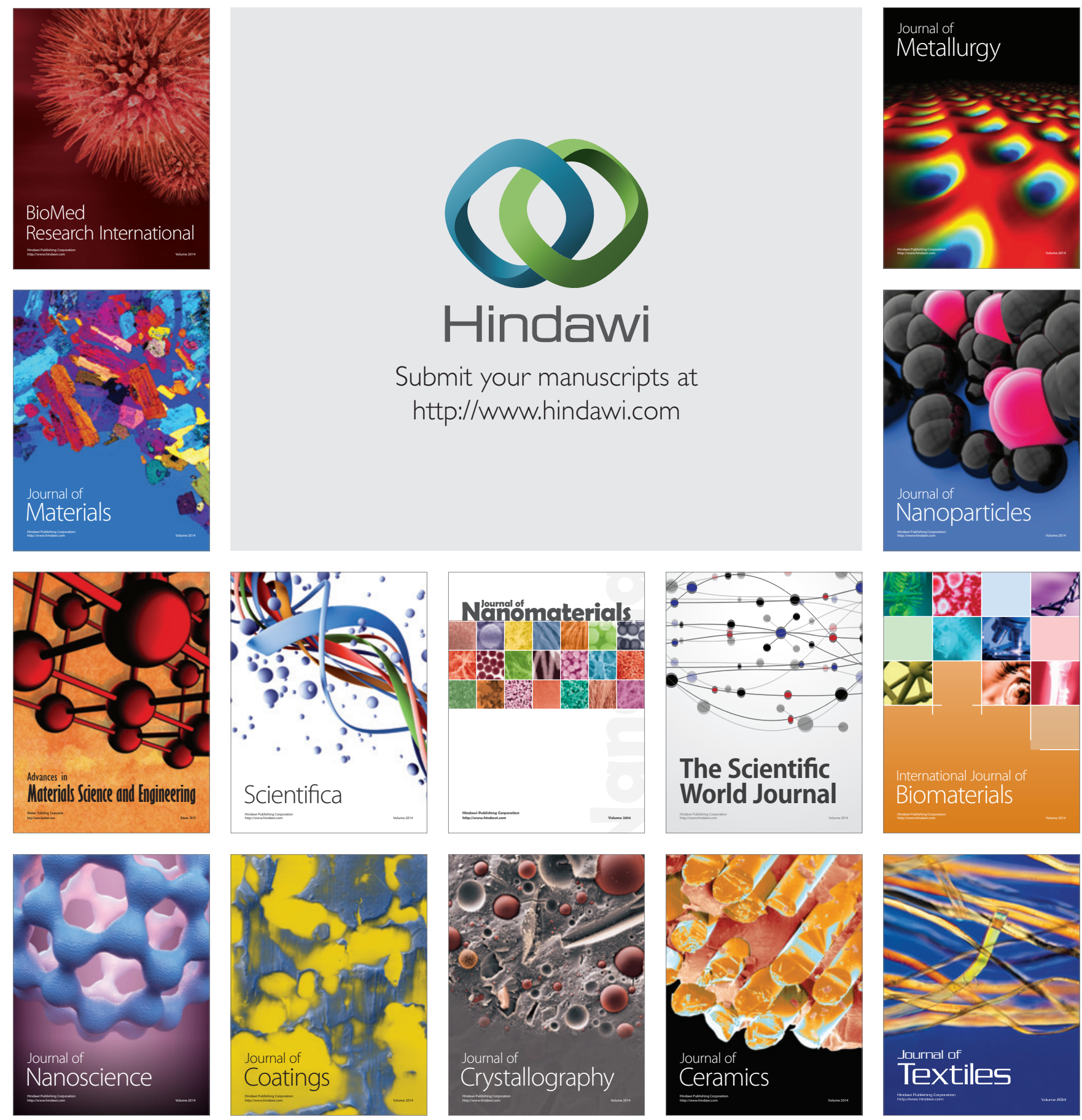